\title{
Estimation of phytochemical constituents and in vitro antioxidant potencies of Brachychiton populneus (Schott \& Endl.) R.Br.
}

\author{
Riffat Batool, Muhammad Rashid Khan*, Moniba Sajid, Saima Ali and Zartash Zahra
}

\begin{abstract}
Background: Plants either in raw form or their isolated bioactive constituents are utilized as complementary and alternative medicine in various disorders. The present study was designed to evaluate chief phytochemical constituents of various fractions of Brachychiton populneus leaves and its antioxidative aptitude against free radicals.

Methods: Various fractions of B. populneus were prepared through solvent-solvent extraction technique based on their polarity and screened for phytochemical classes, total phenolic (TPC), flavonoid (TFC) and total tannin (TTC) content. Antioxidant effects of the extracts were manifested by in vitro multidimensional assays i.e. DPPH, hydroxyl radical scavenging, iron chelating, nitric oxide scavenging, $\beta$-carotene bleaching, phosphomolybdenum and reducing power assay.

Results: Qualitative screening of various fractions of B. populneus ensured the presence of alkaloids, saponins, terpenoids, phenols, tannins, triterpenoids and flavonoids. Quantitative analysis revealed that aqueous fraction (BPA) showed maximum quantity of TPC and TFC followed by BPE and BPB. In terms of IC ${ }_{50}$ values BPA exhibited minimum values in all the in vitro antioxidant assays. However, the phytochemicals and yield did not accumulate in various fractions on polarity.

Conclusion: Our results indicated the presence of various polyphenolics, flavonoids, alkaloids etc. The yield of various fractions and qualitative phytochemical analysis did not correlate with polarity of solvents. Various antioxidant assays exhibited significant $(p<0.05)$ correlation with TPC and TFC and renders B. populneus with therapeutic potential against free-radical-associated oxidative damages and this effect was significant with BPA.
\end{abstract}

Keywords: Brachychiton populneus, Total phenolics, Total flavonoids, Antioxidant

\section{Background}

Phytochemical studies are based on exploring plants for their use in the production of novel therapeutic drugs. Phytonutrients have numerous health benefits, for example, they may have antimicrobial, anti-inflammatory, anti-diabetic, cancer preventive and antihypertensive properties [1]. Herbal medicinal plants synthesize vast range of secondary metabolites having therapeutic potential to cope with oxidative stress caused diseases [2]. The antioxidant activity of medicinal plants is primarily

\footnotetext{
*Correspondence: mrkhanqau@yahoo.com

Department of Biochemistry, Faculty of Biological Sciences, Quaid-i-Azam
} University, Islamabad, Pakistan because of the occurrence of organic substances. Phytochemicals have revealed substantial impact on several pharmaceutical products defining their therapeutic effect which certainly predicts the specific usage and presentation type [3]. Polyphenols enjoy eminent status these days due to latest outcomes and research concerning their biological activities. They are strong antioxidants i.e. are tremendous free radical foragers and inhibitors of lipid peroxidation. Thus have crucial role from pharmacological and therapeutic point of view. Terpenoids are another important class of phytochemicals that are useful for curing obesity induced metabolic disorders [4]. Awareness of chemical components of plants is vibrant for developing new drug products from medicinal plants. 
Modern isolation methods, screening of biological activities and pharmacological challenges led to the development of purified drugs [5].

The antioxidative aptitude of the therapeutic plants and their derived compounds is directly correlated with their strength to quench the reactive radicals by donation of electron; ultimately leading to radical chain reaction termination. Antioxidants can be produced inside the body [e.g., superoxide dismutase (SOD), reduced glutathione (GSH) etc.] or taken as dietetic antioxidants [1]. Plants are a good source of dietary (i.e. exogenous) antioxidants. Two-third of the world's plant species have therapeutic importance, and nearly all of them posses tremendous antioxidant prospective. The curiosity in the exogenous plant antioxidants was first educed by the finding and consequent isolation of ascorbic acid from the plants [6].

Insufficient antioxidant defenses lead to the oxidative stress state during the overwhelming generation of reactive oxygen species (ROS) and reactive nitrogen species (RNS). Among the many devastating conditions, oxidative stress causes damages to the nucleic acid, lipids and proteins. This situation is associated with synthesis of secondary reactive species as a response of oxidation. Such continuous metabolic reactions severely harm the cells inducing various diseases through apoptosis and necrosis. Oxidative dilemma is the root cause of many pathological irregularities of liver, lungs, kidneys, brain and heart [7]. It is suggested by scientific documentation that ROS induced cellular damages can be overcome and neutralized through chemo-deterrence by means of therapeutic herbs and foods. On the basis of past achievements about natural products, a variety of medical vegetation has been appraised in favor of their antioxidative potential [8].

Brachychiton populneus generally known as the Kurrajong is a member of the family Sterculaceae. It is a small to medium-sized tree up to $20 \mathrm{~m}$ in height which generally have a moderately short trunk and a compactly-foliaged pinnacle $[9,10]$. The genus is reported for innumerable chemical compounds including alkaloids, flavonoids, terpenes, sterols and coumarins that have antioxidants, antimicrobial and antidiabetic potencial [11]. Due to absence of prior biological investigation, the main purpose of this study was to elucidate the phytochemical constituents on qualitative as well as quantitative basis of the various fractions of B. populneus and assessment of its antioxidant potential through direct radical foraging methods.

\section{Results}

\section{Qualitative phytochemical analysis}

Qualitative analysis for various phytochemicals viz. alkaloids, anthocyanins, betacyanins, anthraquinones, coumarins, flavonoids, saponins, tannins, terpenoids, glycosides, phenols, steroids, triterpenoids, proteins, vitamin $C$, phlobatannins and sterols was carried out for B. populneus methanol extract and its derived fractions. Results shown in Table 1 indicated that various chemical classes did not obey the polarity of solvents for resolution. These results confirmed the presence of alkaloids, flavonoids, phenols, terpenoids, triterpenoids, quinones, oils and resins, phlobatannins, vitamin $C$, proteins and glycosides in all fractions of $B$. populneus. Coumarins and saponins were present in all the fractions except $\mathrm{BPH}$. Anthraquinones were present in BPM, BPE, BPB and BPA. Betacyanins were present in BPM, BPH and BPA while BPM, BPC, BPE and BPB contained anthocyanins. Steroids and phytosteroids were present in all the fractions except BPA. Presence of sterols was recorded in BPM, BPE, BPB and BPA. Further, BPA contained the maximum phytochemical classes while $\mathrm{BPH}$ showed the least number of existing phytochemicals.

\section{Plant yield and quantitative spectrophotometric phytochemical analysis}

The extraction yield of methanol extract and its various fractions are depicted in Table 2. An amount of $450 \mathrm{~g}$ of dry powder of B. populneus produced $50 \mathrm{~g}$ of crude methanol extract which was progressed with different organic solvents having different polarity index. The yield produced by different solvents during fractionation indicated that it did not follow the polarity of solvents. The maximum yield $17 \mathrm{~g}$ was obtained for $\mathrm{BPA}$ whereas the yield of other fractions; $\mathrm{BPH}, \mathrm{BPC}$, $\mathrm{BPE}$ and $\mathrm{BPB}$ was found to be $13 \mathrm{~g}, 7.8 \mathrm{~g}, 1.5 \mathrm{~g}$ and $8.5 \mathrm{~g}$, respectively. On the basis of standard regression lines for gallic acid (Fig. 1) and rutin (Fig. 2), the equivalents of standards were calculated i.e. mg of gallic acid equivalent/g of dry sample (mg GAE/g dry sample) and $\mathrm{mg}$ of rutin equivalent/g of dry sample (mg RE/g dry sample) (Table 2). B. populneus aqueous fraction (BPA) showed maximum quantity of TFC (126.7 $\pm 1.15 \mathrm{mg}$ RE/g dry sample) followed by BPE $(119.7 \pm 2.1 \mathrm{mg} \mathrm{RE} / \mathrm{g}$ dry sample), BPB (107.7 $\pm 1.4 \mathrm{mg}$ RE/g dry sample), BPM $(99.1 \pm 1.05 \mathrm{mg} \mathrm{RE} / \mathrm{g}$ dry sample), BPC (78.6 $\pm 1.3 \mathrm{mg}$ $\mathrm{RE} / \mathrm{g}$ dry sample) and BPH (70.9 $\pm 2 \mathrm{mg} \mathrm{RE} / \mathrm{g}$ dry sample) as shown in Table 2. TPC were found to be rich in BPA (189.2 $\pm 1.6 \mathrm{mg}$ GAE/g dry sample) followed by BPE $(174.4 \pm 1.2 \mathrm{mg} \mathrm{GAE} / \mathrm{g}$ dry sample), BPB $(162.9 \pm 0.9 \mathrm{mg}$ GAE/g dry sample), BPM (156.6 $\pm 1.17 \mathrm{mg}$ GAE/g dry sample), BPC (149.2 $\pm 2.1 \mathrm{mg}$ GAE/g dry sample) and $\mathrm{BPH}(139.4 \pm 2 \mathrm{mg}$ GAE/g dry sample). Total tannin content (TTC) was quantified spectrophotometrically as highest in BPE $(383.63 \pm 0.8 \mathrm{mg}$ of GAE/g dry sample) successively followed by BPA $(351.17 \pm 0.7 \mathrm{mg}$ of GAE/g dry sample), BPM (280.43 $\pm 0.5 \mathrm{mg}$ of $\mathrm{GAE} / \mathrm{g}$ 
Table 1 Phytochemical analysis of Brachychiton populneus leaves methanol extract and derived fractions

\begin{tabular}{|c|c|c|c|c|c|c|}
\hline \multirow[t]{2}{*}{ Compound class } & \multicolumn{6}{|c|}{ Extracts/fractions } \\
\hline & BPM & $\mathrm{BPH}$ & BPC & BPE & BPB & BPA \\
\hline \multicolumn{7}{|l|}{ Alkaloids } \\
\hline Mayer's test & ++ & + & + & +++ & ++ & +++ \\
\hline Hager's test & +++ & + & + & +++ & +++ & +++ \\
\hline \multicolumn{7}{|l|}{ Tannins } \\
\hline $\mathrm{FeCl}_{3}$ test & + & + & + & ++ & ++ & ++ \\
\hline Alkaline reagent test & ++ & + & + & ++ & + & ++ \\
\hline Phenols & ++ & + & + & +++ & +++ & +++ \\
\hline \multicolumn{7}{|l|}{ Flavonoids } \\
\hline Alkaline reagent test & ++ & + & ++ & +++ & ++ & +++ \\
\hline $\mathrm{FeCl}_{3}$ test & ++ & + & + & +++ & +++ & +++ \\
\hline Anthraquinones & + & - & - & + & + & ++ \\
\hline Betacyanins & ++ & + & - & - & - & + \\
\hline Anthocyanins & + & - & ++ & +++ & + & - \\
\hline Terpenoides & ++ & + & ++ & +++ & ++ & +++ \\
\hline \multicolumn{7}{|l|}{ Saponins } \\
\hline Froth test & + & - & + & ++ & + & + \\
\hline Emulsion test & ++ & - & + & ++ & ++ & ++ \\
\hline Coumarins & + & - & + & ++ & + & + \\
\hline Glycosides & ++ & + & + & +++ & +++ & +++ \\
\hline Sterols & + & - & - & + & + & ++ \\
\hline Oils and resins & + & +++ & + & + & ++ & + \\
\hline Quinones & + & + & ++ & ++ & ++ & ++ \\
\hline Triterpenoids & ++ & +++ & ++ & + & + & + \\
\hline Phlobatannins & ++ & +++ & ++ & + & + & + \\
\hline Steroids and phytosteroids & + & ++ & ++ & + & + & - \\
\hline Vitamin C & ++ & + & ++ & +++ & ++ & +++ \\
\hline \multicolumn{7}{|l|}{ Proteins } \\
\hline Xanthoproteic test & + & + & + & +++ & ++ & + \\
\hline Biuret test & ++ & + & + & ++ & ++ & ++ \\
\hline
\end{tabular}

(+) present, $(-)$ absent, $(++)$ moderate concentration, $(+++)$ abundant concentration

BPM: B. populneus methanol extract; BPH: B. populneus $n$-hexane fraction; BPC; $B$. populneus chloroform fraction; BPE: $B$. populneus ethyl acetate fraction; BPB: $B$. populneus butanol fraction; BPA: $B$. populneus aqueous fraction

dry sample), BPB (235.3 $\pm 0.6 \mathrm{mg}$ of GAE/g dry sample) whereas BPC and BPH $(72.5 \pm 0.65$ and $53.8 \pm 0.36 \mathrm{mg}$ of GA/g extract) lagged afterwards as shown in Table 2. On the whole the yield accumulated for various fractions did not strictly correlate with the polarity of various solvents used in this study.

\section{Quantitative non-spectrophotometric phytochemical analysis}

Various fractions of $B$. populneus were quantified for major phytochemicals including alkaloids, terpenoids, flavonoids and saponins whose presence was observed in qualitative phytochemical analysis directed preliminarily. All results were expressed as percent of yield/g of sample as presented in Table 3. Maximum amount of alkaloids was detected in BPA $(18.1 \pm 0.27)$ followed by BPE $(16.7 \pm 0.55)$. BPB, BPM, BPC and BPH trailed behind as shown in Table 3. Terpenoids were weighed maximum in $\mathrm{BPH}(17.2 \pm 0.73)$ sequentially tracked by BPC $(12.9 \pm 0.85)$, BPM $(10.97 \pm 0.35)$, BPE $(9.5 \pm 0.21)$ and $\mathrm{BPB}(8.7 \pm 0.21)$, while the least terpenoid content was displayed by BPA $(6.5 \pm 0.55)$. Flavonoid percentage was detected highest in BPE $(15.7 \pm 0.2)$ followed closely by BPA $(14.3 \pm 0.7)$. BPB presented flavonoid percentage of $10.8 \pm 0.21$, whereas $\mathrm{BPH}$ showed minimal amount of flavonoids $(2.21 \pm 0.6)$. Saponins were quantified as highest in BPM $(20.4 \pm 0.29)$ followed by $\mathrm{BPB}(17.3 \pm 0.5)$, BPA $(16.1 \pm 0.26)$, BPE $(14.8 \pm 0.41)$ 
Table 2 Estimation of plant extraction yield, total phenolics, flavonoids, tannins, antioxidant capacity and reducing power of Brachychiton populneus leaves

\begin{tabular}{|c|c|c|c|c|c|c|}
\hline Sample & Yield $(\mathbf{g})^{\mathbf{g}}$ & $\begin{array}{l}\text { Total phenolic } \\
\text { contents expressed } \\
\text { as gallic acid } \\
\text { equivalents ( } \mathrm{mg} / \mathrm{g} \\
\text { of extract) }\end{array}$ & $\begin{array}{l}\text { Total flavonoid } \\
\text { contents expressed } \\
\text { as rutin equivalents } \\
\text { (mg/g of extract) }\end{array}$ & $\begin{array}{l}\text { Total tannin content } \\
\text { expressed as gallic } \\
\text { acid equivalents } \\
\text { (mg/g of extract) }\end{array}$ & $\begin{array}{l}\text { Total antioxidant } \\
\text { capacity expressed } \\
\text { as ascorbic acid } \\
\text { equivalents (mg/g } \\
\text { of extract) }\end{array}$ & $\begin{array}{l}\text { Total reducing power } \\
\text { expressed as ascorbic } \\
\text { acid equivalents ( } \mathrm{mg} / \mathrm{g} \\
\text { of extract) }\end{array}$ \\
\hline BPM & 50 & $156.6 \pm 1.17^{d}$ & $99.1 \pm 1.05^{d}$ & $280.43 \pm 0.5^{c}$ & $685.4 \pm 2.05^{c}$ & $885.4 \pm 2.06^{d}$ \\
\hline $\mathrm{BPH}$ & 13 & $139.4 \pm 2^{f}$ & $70.9 \pm 2^{f}$ & $53.8 \pm 0.36^{f}$ & $555.6 \pm 1.1^{\mathrm{e}}$ & $822.3 \pm 1.8^{f}$ \\
\hline $\mathrm{BPC}$ & 7.8 & $149.2 \pm 2.1^{e}$ & $78.6 \pm 1.3^{\mathrm{e}}$ & $72.5 \pm 0.65^{e}$ & $592.5 \pm 1.37^{d}$ & $850.19 \pm 2.6^{\mathrm{e}}$ \\
\hline BPE & 1.5 & $174.4 \pm 1.2^{b}$ & $119.7 \pm 2.1^{b}$ & $383.63 \pm 0.8^{\mathrm{a}}$ & $759.03 \pm 2.28^{b}$ & $956.2 \pm 1.71^{b}$ \\
\hline BPB & 8.5 & $162.9 \pm 0.9^{c}$ & $107.7 \pm 1.4^{c}$ & $235.3 \pm 0.6^{d}$ & $685.4 \pm 1.29^{c}$ & $933.6 \pm 3.04^{c}$ \\
\hline BPA & 17 & $189.2 \pm 1.6^{\mathrm{a}}$ & $126.7 \pm 1.15^{\mathrm{a}}$ & $351.17 \pm 0.7^{b}$ & $851.65 \pm 2.2^{\mathrm{a}}$ & $988.34 \pm 2.1^{\mathrm{a}}$ \\
\hline
\end{tabular}

BPM: B. populneus methanol extract; BPH: B. populneus $n$-hexane fraction; BPC: B. populneus chloroform fraction; BPE: B. populneus ethyl acetate fraction; BPB: B. populneus butanol fraction; BPA: B. populneus aqueous fraction

Each value is represented as mean $\pm S D(n=3)$. Means with different superscript $\left.{ }^{a-f}\right)$ letters in the rows are significantly $(p<0.01)$ different from one another

9 Yield of BPM is based on the dry powder; the yield of its fractions is based on the yield of BPM

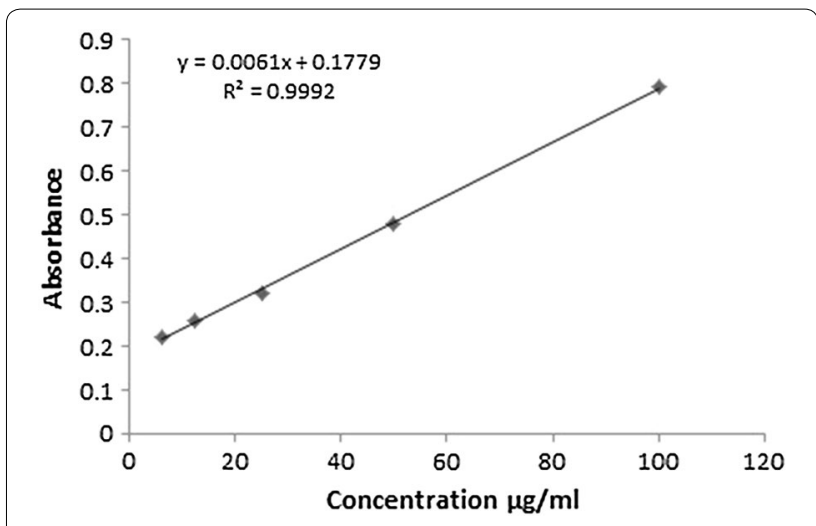

Fig. 1 Regression line of gallic acid with total phenolic content

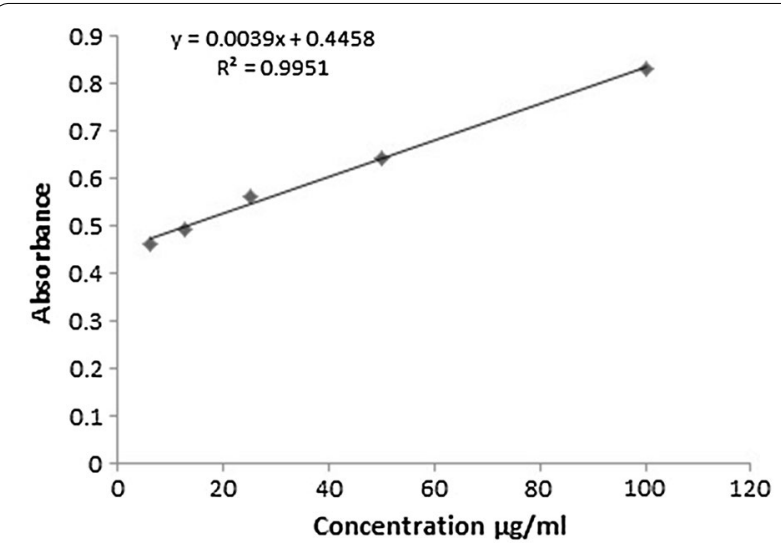

Fig. 2 Regression line of rutin with total flavonoid contents and BPC $(12.5 \pm 0.72)$ whereas least in $\mathrm{BPH}(8.0 \pm 0.11)$ (Table 3).

\section{In vitro antioxidant activities DPPH radical scavenging activity}

The $\mathrm{IC}_{50}$ values of DPPH radical scavenging activity of B. populneus extract/fractions are shown in Table 4. Best values for $\mathrm{IC}_{50}$ were exhibited by BPA $(46.51 \pm 2.1 \mu \mathrm{g} / \mathrm{ml})$ followed by BPE $(48.32 \pm 2.1 \mu \mathrm{g} / \mathrm{ml})$, BPB $(63.38 \pm 3.4 \mu \mathrm{g} /$ $\mathrm{ml})$, BPM $(143.7 \pm 2.7 \mu \mathrm{g} / \mathrm{ml}), \mathrm{BPC}(259.6 \pm 3.3 \mu \mathrm{g} / \mathrm{ml})$ and BPH $(461.7 \pm 1.5 \mu \mathrm{g} / \mathrm{ml})$. The observed order of $\mathrm{IC}_{50}$ of different fractions was $\mathrm{BPA}<\mathrm{BPE}<\mathrm{BPB}<\mathrm{BPM}<\mathrm{BPC}<$ $\mathrm{BPH}$. The DPPH radical scavenging activity of extract and its various fractions showed significant correlation with TPC $\left(R^{2}=0.8529^{* * *}, \mathrm{p}<0.01\right)$ and TFC $\left(\mathrm{R}^{2}=0.8567^{* * *}\right.$, $\mathrm{p}<0.01)$ (Table 5). All the fractions showed higher $\mathrm{IC}_{50}$ values than ascorbic acid $(29.57 \pm 1.1 \mu \mathrm{g} / \mathrm{ml})$. Concentration dependent activity was observed as illustrated in Fig. 3.

\section{Hydroxyl radical $(\cdot \mathrm{OH})$ scavenging activity}

All the extract/fractions of $B$. populneus scavenged $\bullet \mathrm{OH}$ radicals and prevented 2-deoxyribose breakdown in this assay. A concentration-dependent pattern was observed for hydroxyl radical scavenging activity (Fig. 3). Lowest $\mathrm{IC}_{50}$ values were shown by BPA and BPE $(144.3 \pm 3.2 \mu \mathrm{g} /$ $\mathrm{ml}$ and $180.5 \pm 3.6 \mu \mathrm{g} / \mathrm{ml}$ ) respectively followed by BPB $\quad(255.0 \pm 2.2 \mu \mathrm{g} / \mathrm{ml}), \quad$ BPM $\quad(345.6 \pm 2.1 \mu \mathrm{g} / \mathrm{ml})$ while the highest $\mathrm{IC}_{50}$ was observed for $\mathrm{BPH}$ and $\mathrm{BPC}$ $(618.3 \pm 4.0 \mu \mathrm{g} / \mathrm{ml}$ and $764.8 \pm 2.5 \mu \mathrm{g} / \mathrm{ml})$ respectively. $\mathrm{IC}_{50}$ values of different fractions were significantly different from the used standard rutin $(110.7 \pm 1.7 \mu \mathrm{g} / \mathrm{ml})$. 
Table 3 Non-spectrophotometric phytochemical analysis of B. populneus and its derived fractions

\begin{tabular}{lcccr}
\hline $\begin{array}{l}\text { Plant } \\
\text { extracts/ } \\
\text { fractions }\end{array}$ & \multicolumn{4}{l}{ Percentage (\%) yield per gram } \\
\cline { 2 - 5 } & Alkaloids & Flavonoids & Saponins & Terpenoids \\
\hline BPM & $6.93 \pm 0.51$ & $5.96 \pm 0.33$ & $20.4 \pm 0.29$ & $10.97 \pm 0.35$ \\
BPH & $2.3 \pm 0.75$ & $2.21 \pm 0.6$ & $8.0 \pm 0.11$ & $17.2 \pm 0.73$ \\
BPC & $3.8 \pm 0.37$ & $7.29 \pm 0.52$ & $12.5 \pm 0.72$ & $12.9 \pm 0.85$ \\
BPE & $16.7 \pm 0.55$ & $15.74 \pm 0.2$ & $14.8 \pm 0.41$ & $9.5 \pm 0.40$ \\
BPB & $10.2 \pm 0.4$ & $10.8 \pm 0.21$ & $17.3 \pm 0.5$ & $8.7 \pm 0.21$ \\
BPA & $18.1 \pm 0.27$ & $14.3 \pm 0.7$ & $16.1 \pm 0.26$ & $6.5 \pm 0.55$ \\
\hline
\end{tabular}

Mean $\pm \mathrm{SD}(\mathrm{n}=3)$

BPM: B. populneus methanol extract; BPH: B. populneus $n$-hexane fraction; BPC: B. populneus chloroform fraction; BPE: $B$. populneus ethyl acetate fraction; BPB: $B$. populneus butanol fraction; BPA: B. populneus aqueous fraction

Overall pattern of $\mathrm{BPA}<\mathrm{BPE}<\mathrm{BPB}<\mathrm{BPM}<\mathrm{BPH}<\mathrm{BPC}$ was observed (Table 4). A good correlation $\left(R^{2}=0.7216^{*}\right.$, $\mathrm{p}<0.01)$ was observed with TPC as well as $\left(\mathrm{R}^{2}=0.8881^{* *}\right.$, $\mathrm{p}<0.01$ ) with TFC (Table 5).

\section{Nitric oxide $\left(\mathrm{NO}^{-}\right)$scavenging activity}

In the present study, the lowest $\mathrm{IC}_{50}$ value for nitric oxide scavenging activity was observed for BPA $(46.49 \pm 2.7 \mu \mathrm{g} / \mathrm{ml})$ and BPE $(82.7 \pm 3.08 \mu \mathrm{g} /$ $\mathrm{ml})$ followed by BPB $(121.2 \pm 2.5 \mu \mathrm{g} / \mathrm{ml}), \quad$ BPM $(130.0 \pm 2.9 \mu \mathrm{g} / \mathrm{ml}), \mathrm{BPC}(165.5 \pm 2.7 \mu \mathrm{g} / \mathrm{ml})$ and $\mathrm{BPH}$ $(180.4 \pm 3.3 \mu \mathrm{g} / \mathrm{ml})$ as compared to standard ascorbic acid $(16.4 \pm 1.6 \mu \mathrm{g} / \mathrm{ml})$ as shown in Table 4 . The $\%$ inhibition pattern is shown in Fig. 3. A highly significant $(\mathrm{p}<0.01)$ correlation of $\mathrm{IC}_{50}$ was observed with TPC $\left(R^{2}=0.988^{* * * *}, p<0.001\right)$ and TFC $\left(R^{2}=0.9494^{* * * *}\right.$, $\mathrm{p}<0.001$ ) (Table 5).

\section{$\beta$-Carotene scavenging activity}

The BPA of B. populneus showed the lowest $\mathrm{IC}_{50}$ value $(40.04 \pm 3.1 \mu \mathrm{g} / \mathrm{ml})$ as compared to other fractions viz. BPE $(77.9 \pm 1.5 \mu \mathrm{g} / \mathrm{ml})$, BPB $(115.3 \pm 2.1 \mu \mathrm{g} / \mathrm{ml})$, BPM $(148.8 \pm 2.3 \mu \mathrm{g} / \mathrm{ml}), \mathrm{BPC}(244.8 \pm 2.8 \mu \mathrm{g} / \mathrm{ml})$ and $\mathrm{BPH}$ $(347.3 \pm 3.6 \mu \mathrm{g} / \mathrm{ml})$. All the fractions showed higher $\mathrm{IC}_{50}$ values than catechin $(58.4 \pm 2.8 \mu \mathrm{g} / \mathrm{ml})$ while $\mathrm{IC}_{50}$ value of BPA was lower than catechin as shown in Table 4 . The concentration dependent bleaching power pattern observed is shown in Fig. 3. The $\mathrm{IC}_{50}$ values showed significant correlation with both TPC $\left(\mathrm{R}^{2}=0.8764^{* * *}\right.$, $\mathrm{p}<0.01)$ and TFC $\left(\mathrm{R}^{2}=0.9566^{* * * *}, \mathrm{p}<0.001\right)($ Table 5).

\section{Iron chelating activity}

$\mathrm{IC}_{50}$ values for Iron chelating activity of different fractions of B. populneus are given in (Table 4). The best $\mathrm{IC}_{50}$ value for iron chelating activity was exhibited by

Table 5 Correlation of $\mathrm{IC}_{50}$ values of different antioxidant activities with total phenolic and total flavonoid contents

\begin{tabular}{lll}
\hline Antioxidant activity & \multicolumn{2}{l}{ Correlation $\mathbf{R}^{\mathbf{2}}$} \\
\cline { 2 - 3 } & TFC & TPC \\
\hline DPPH scavenging activity & $0.856^{* *}$ & $0.852^{* *}$ \\
Hydroxyl radical scavenging activity & $0.888^{* *}$ & $0.721^{*}$ \\
Iron chelating assay & $0.988^{* * *}$ & $0.872^{* *}$ \\
Nitric oxide scavenging activity & $0.949^{* * *}$ & $0.988^{* * *}$ \\
$\beta$-Carotene bleaching activity & $0.956^{* * *}$ & $0.876^{* *}$ \\
Total antioxidant activity & $0.941^{* * *}$ & $0.977^{* * *}$ \\
Total reducing power assay & $0.978^{* * *}$ & $0.953^{* *}$ \\
\hline
\end{tabular}

TFC: total flavonoid content; TPC: total phenolic content

Column with different ${ }^{*}, * * * * *$ are significantly different at $p<0.05, p<0.01$ and $\mathrm{p}<0.001$

Table 4 IC $_{50}$ values of different antioxidant activities of BPM and its fractions

\begin{tabular}{|c|c|c|c|c|c|}
\hline Sample & DPPH scavenging & $\begin{array}{l}\text { Hydroxyl radical } \\
\text { scavenging }\end{array}$ & $\begin{array}{l}\text { Nitric oxide } \\
\text { scavenging activity }\end{array}$ & $\begin{array}{l}\beta \text {-carotene bleaching } \\
\text { inhibition activity }\end{array}$ & Iron chelating activity \\
\hline & $\mathrm{IC}_{50}(\mu \mathrm{g} / \mathrm{ml})$ & & & & \\
\hline BPM & $143.7 \pm 2.7^{c}$ & $345.6 \pm 2.1^{c}$ & $130 \pm 2.9^{c}$ & $148.8 \pm 2.3^{c}$ & $761.5 \pm 1.9^{c}$ \\
\hline $\mathrm{BPH}$ & $461.7 \pm 1.5^{\mathrm{a}}$ & $618.3 \pm 4.0^{\mathrm{b}}$ & $180.4 \pm 3.3^{\mathrm{a}}$ & $347.3 \pm 3.6^{\mathrm{a}}$ & $>1000$ \\
\hline BPC & $259.6 \pm 3.3^{b}$ & $764.8 \pm 2.5^{\mathrm{a}}$ & $165.5 \pm 2.7^{b}$ & $244.8 \pm 2.8^{b}$ & $>1000$ \\
\hline BPE & $48.32 \pm 2.1^{\mathrm{e}}$ & $180.5 \pm 3.6^{\mathrm{e}}$ & $82.7 \pm 3.08^{d}$ & $77.9 \pm 1.5^{\mathrm{e}}$ & $336.7 \pm 1.8^{e}$ \\
\hline BPB & $63.38 \pm 3.4^{d}$ & $255.0 \pm 2.2^{d}$ & $121.2 \pm 2.5^{c}$ & $115.3 \pm 2.1^{d}$ & $605.4 \pm 2.3^{d}$ \\
\hline BPA & $46.51 \pm 2.1^{e}$ & $144.3 \pm 3.2^{f}$ & $46.49 \pm 2.7^{e}$ & $40.04 \pm 3.1^{9}$ & $249.8 \pm 2.8^{f}$ \\
\hline Rutin & - & $110.7 \pm 1.7^{9}$ & - & - & - \\
\hline Ascorbic acid & $29.57 \pm 1.1^{f}$ & - & $16.4 \pm 1.6^{f}$ & - & - \\
\hline Catechin & - & - & - & $58.4 \pm 2.8^{f}$ & - \\
\hline EDTA & - & - & - & - & $177.2 \pm 2.8^{\mathrm{g}}$ \\
\hline
\end{tabular}

Values are presented as mean $\pm S D(n=3)$. Means with different superscript $(a-g)$ letters in the rows are significantly $(p<0.01)$ different from each other BPM: B. populneus methanol extract; BPH: B. populneus $n$-hexane fraction; BPC: $B$. populneus chloroform fraction; BPE: $B$. populneus ethyl acetate fraction; BPB: $B$. populneus butanol fraction; BPA: B. populneus aqueous fraction 

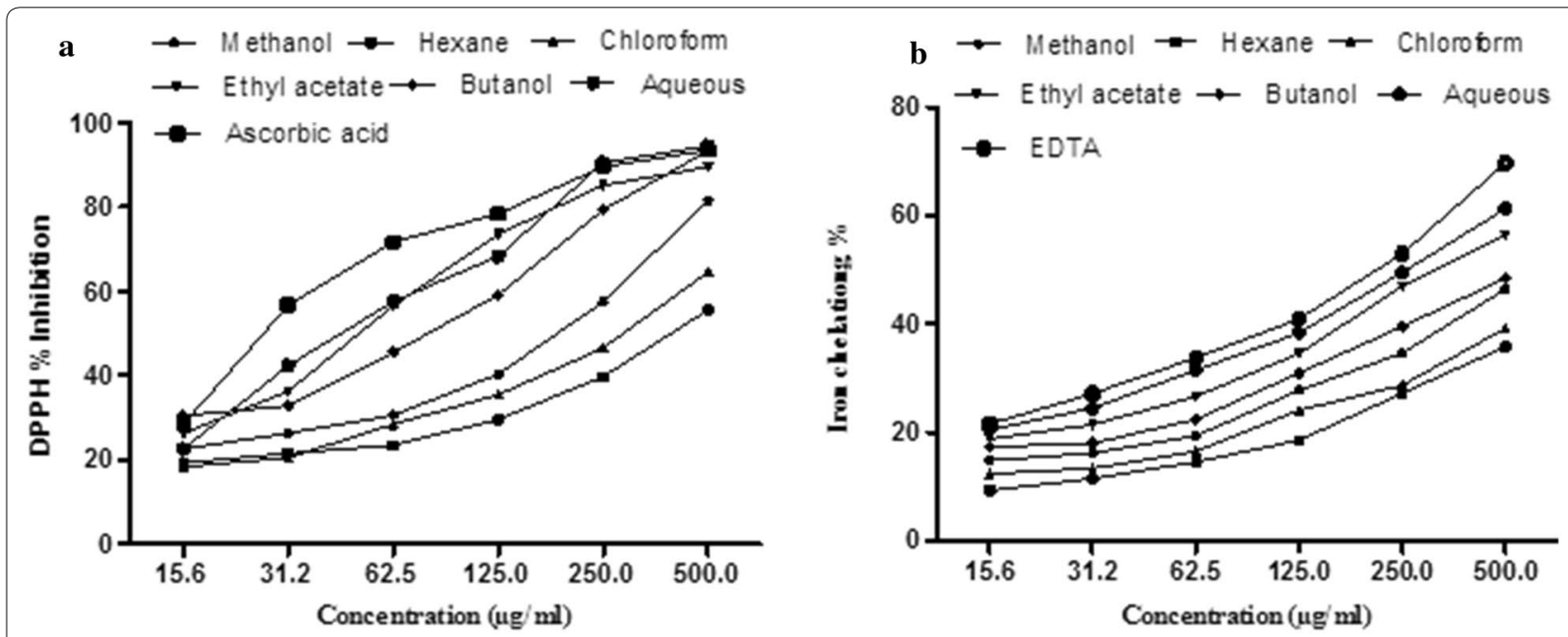

C $\rightarrow$ Methanol $\rightarrow$ Hexane $\rightarrow$ Chloroform
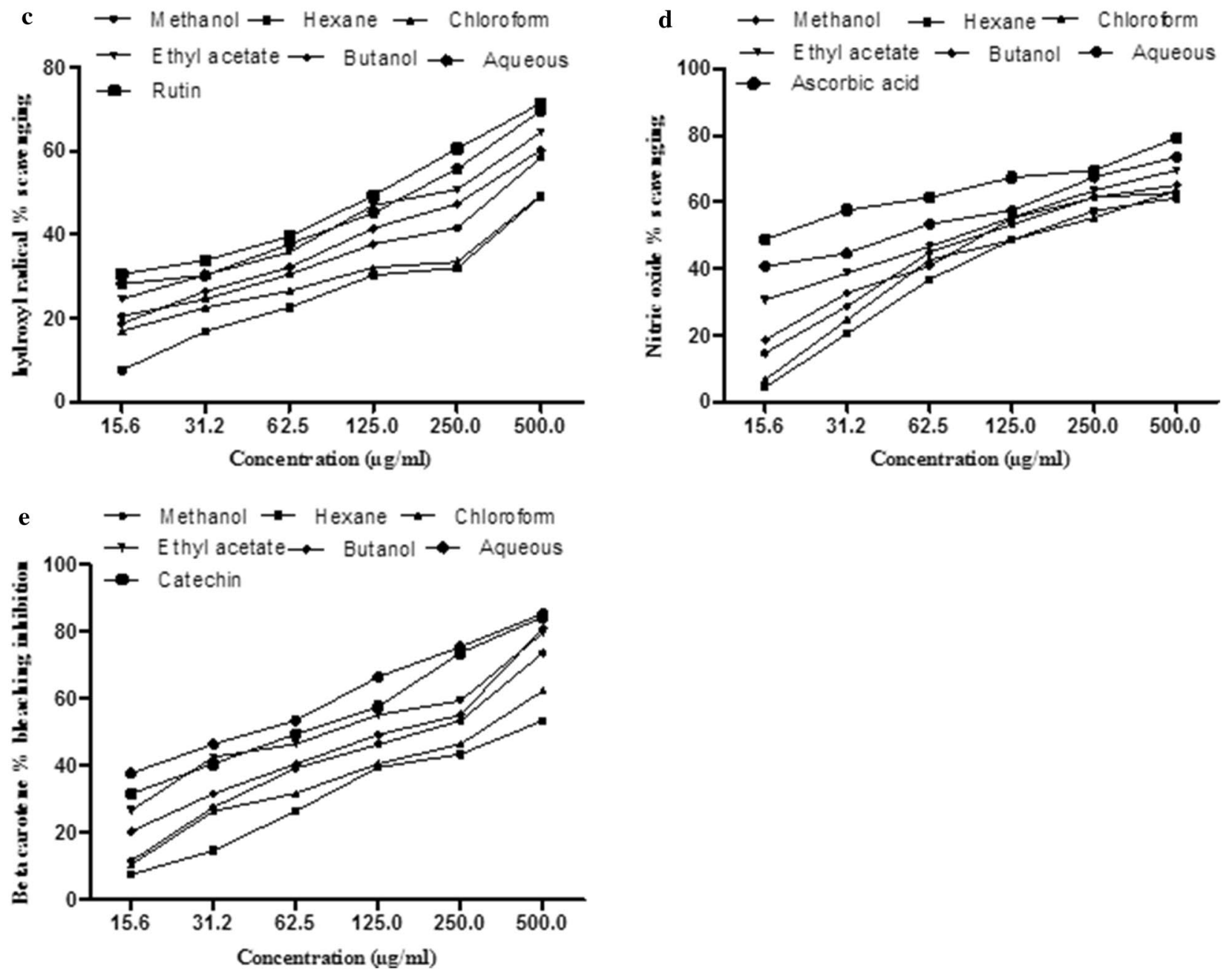

Fig. 3 Effect of different concentrations of BPM and its derived fractions on various in vitro antioxidant assays. a DPPH percent inhibition, $\mathbf{b}$ percent of iron chelation, $\mathbf{c}$ hydroxyl radical percent scavenging, $\mathbf{d}$ nitric oxide percent scavenging, $\mathbf{e} \beta$-carotene bleaching percent inhibition 
BPA $(249.8 \pm 2.8 \mu \mathrm{g} / \mathrm{ml})$ followed by BPE $(336.7 \pm 1.8 \mu \mathrm{g} /$ $\mathrm{ml})$, BPB $(605.5 \pm 2.3 \mu \mathrm{g} / \mathrm{ml})$ and BPM $(761.6 \pm 1.9 \mu \mathrm{g} /$ $\mathrm{ml})$ while $\mathrm{BPC}$ and $\mathrm{BPH}$ showed the higher $\mathrm{IC}_{50}$ values $(>1000 \mu \mathrm{g} / \mathrm{ml})$. IC I0 $_{50}$ value of standard EDTA was $177.2 \pm 2.8 \mu \mathrm{g} / \mathrm{ml}$ as shown in Table 3. Significant correlation of $\mathrm{IC}_{50}\left(\mathrm{R}^{2}=0.8721^{* * *}, \mathrm{p}<0.01\right)$ was observed with TPC and also with TFC $\left(\mathrm{R}^{2}=0.9888^{* * * * *}, \mathrm{p}<0.001\right)$ as listed in Table 5 . The $\%$ inhibition of iron chelating assay is depicted in Fig. 3.

\section{Phosphomolybdenum assay}

Total antioxidant capacity of various extract/fractions was determined by phosphomolybdate method and expressed as equivalents of ascorbic acid ( $\mathrm{mg} / \mathrm{g}$ of extract) at $500 \mu \mathrm{g} / \mathrm{ml}$ sample as shown in Fig. 4a. Maximum antioxidant activity was shown by BPA $(851.6 \pm 2.2 \mathrm{mg}$ ascorbic acid equivalents/g sample) followed by BPE (759.03 $\pm 2.28 \mathrm{mg}$ ascorbic acid equivalents/g sample), BPB $(685.4 \pm 0.86 \mathrm{mg}$ ascorbic acid equivalents/g sample), BPM $(685.4 \pm 205 \mathrm{mg}$ ascorbic acid equivalents/g sample), BPC $(592.5 \pm 1.37 \mathrm{mg}$ ascorbic acid equivalents/g sample) and BPH (555.6 $\pm 1.1 \mathrm{mg}$ ascorbic acid equivalents/g sample) and was found to decrease in the order of $\mathrm{BPA}>\mathrm{BPE}>\mathrm{BPB}>\mathrm{BPM}>\mathrm{BPC}>\mathrm{BPH}$. The assay showed highly significant $(\mathrm{p}<0.001)$ correlation with TPC $\left(R^{2}=0.9774^{* * * *}\right)$ and TFC $\left(R^{2}=0.9412^{* * * *}\right)$ (Table 5).

\section{Reducing power activity}

Brachychiton populneus aqueous fraction showed the highest reducing power $(988.34 \pm 2.1 \mathrm{mg}$ ascorbic acid equivalent/g sample) measured at $500 \mu \mathrm{g} / \mathrm{ml}$ of extract concentration followed by BPE $(956.2 \pm 1.71 \mathrm{mg}$ ascorbic acid equivalents/g sample), BPB (933.6 $\pm 3.04 \mathrm{mg}$ ascorbic acid equivalents/g sample), BPM $(885.4 \pm 2.06 \mathrm{mg}$ ascorbic acid equivalents/g sample), BPC $(850.19 \pm 2.6 \mathrm{mg}$ ascorbic acid equivalents/g sample) and $\mathrm{BPH}(822.3 \pm 1.8 \mathrm{mg}$ ascorbic acid equivalents/g sample) as shown in Fig. 4b. There was exhibited a significant correlation $(\mathrm{p}<0.001)$ with both TPC $\left(\mathrm{R}^{2}=0.9534^{* * * *}\right)$ and TFC $\left(\mathrm{R}^{2}=0.9783^{* * * *}\right)($ Table 5$)$.

\section{Discussion}

Medicinal plants contain variety of chemical constituents that differ from each other regarding polarity and other chemical properties. Isolation of chemical compounds from plants through solvents of different polarity is frequently practiced in phytochemistry [12]. Depending upon the nature of solvents, different extracts yield differently as described by Shah et al. [13]. So, in the present study, maximum yield was obtained in BPA followed by $\mathrm{BPH}$ while BPE produced the minimum yield. Contrary to our results Sahreen et al. [14] reported the lowest yield for hexane fraction in the roots of Rumex hastatus.

Therapeutic propensity of the plants can be assessed by performing initial qualitative screening to ensure the presence of phytochemicals. In the conducted study bioactive constituents that confer biologically dynamic nature to the plants were screened and the results confirmed the existence of coumarins, terpenoids, flavonoids, tannins, alkaloids, phenols, saponins, quinones, phytosteroids, triterpenoids, vitamin $\mathrm{C}$, phlobatannins, sterols, glycosides and betacyanin in BPM. In this study the solvents were unable to resolve the presence of phytochemicals on the polarity basis and most of these phytochemicals were in different fractions. Similar results were recorded in other studies [15]. However, $n$-hexane solvent was able to resolve the presence of some phytochemicals and BPH did not constitute anthraquinones, anthocyanins, saponins, coumarins and sterols that were
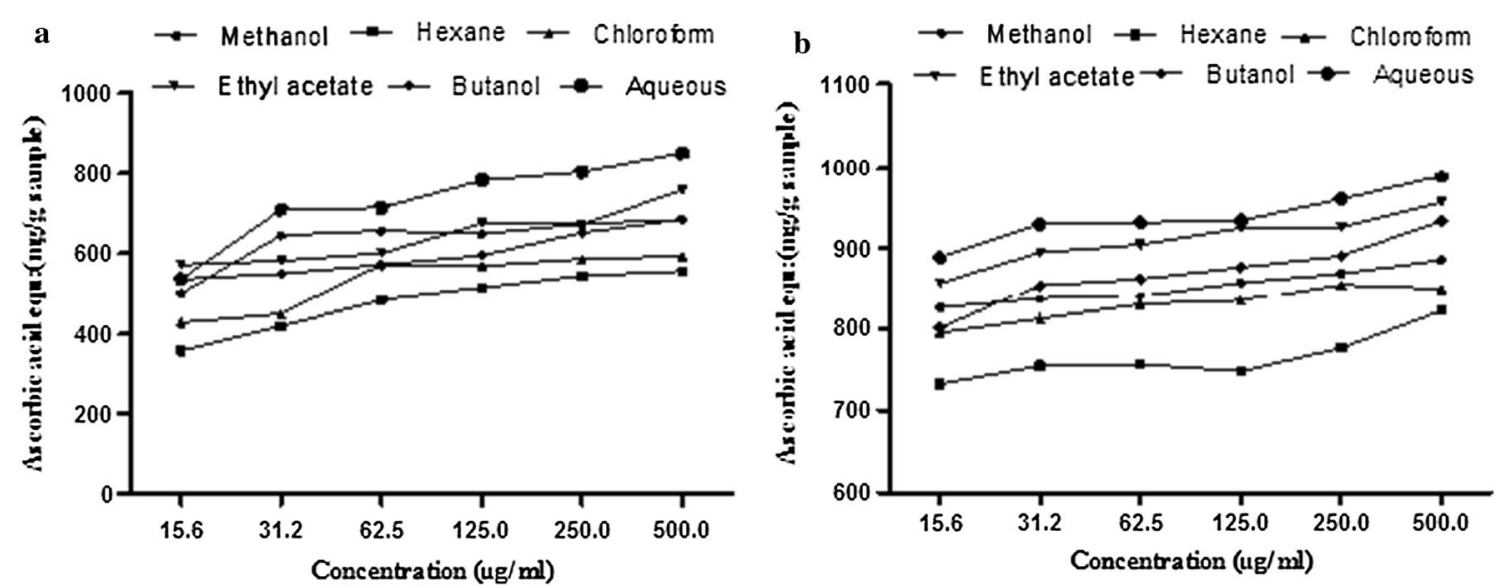

Fig. 4 a Total antioxidant activity (phosphomolybdate assay), $\mathbf{b}$ reducing power assay of BPM and its fractions 
present in BPM. These results suggest the poor solubility of these phytochemicals in $n$-hexane. Apart from this, quantitative spectrophotometric and non-spectrophotometric phytochemical analysis unraveled considerable amount of saponins, alkaloids, flavonoids, phenols, tannins and terpenoids to be present in various fractions of B. populneus. These results suggest that ethyl acetate is the solvent of choice for maximum extraction of total phenolic and tannins whereas aqueous fraction accumulated maximum quantity of total flavonoids. The polarity based resolution of chemicals provides a choice for the use of fraction in a particular disorder.

Compounds belonging to the respective groups have been reported to impart various medicinal characteristics to the plants. Tannins are the polyphenolic compounds obtained from plants, have tremendous activity against diarrhea, hemorrhage, virus and hemorrhoids, bacteria, fungi and parasites and also impart anti-cancer and cytotoxic activity [16]. Flavonoids and phenols have vital scavenging role in oxidation, inflammation and cancer [17]. Alkaloids are said to have impact on neurological disorders like Alzheimer's disease [18] and also have been reported for anticancer activities [19]. Saponins have ability to cope with pests, bacteria and fungi [20]. Presence of these compounds justifies the therapeutic potential of B. populneus.

To assess and verify the presence of antioxidant capabilities within plants, a variety of antioxidant assays have been established with varying mechanics and kinetics. These assays enquire the plants in diverse ways before certifying it as an antioxidant. So to appraise the antioxidant capacity of polarity based crude extracts of $B$. populneus viz. $\mathrm{BPM}, \mathrm{BPH}, \mathrm{BPE}, \mathrm{BPC}, \mathrm{BPB}$ and $\mathrm{BPA}$, a series of antioxidant assays were conducted.

Scavenging activity of B. populneus extract for free radicals was estimated by DPPH assay. It is very sensitive and short time assay for checking the antioxidant potential of the plant extracts and compounds. DPPH is one of a stable, nitrogen centered dark violet colored powder which changes from violet to yellow color upon reduction [21]. The change in color extent depends upon scavenging capabilities of antioxidant crude extract or an isolated pure compound as it reduces the DPPH radical by donating hydrogen [22]. Presence of phenolics and flavonoids impart the scavenging capabilities to the plant. Phenolics and flavonoids are greatly extracted in the polar solvents which show good scavenging abilities as they donate electron or hydrogen to stabilize DPPH free radicals. In current study the aqueous fraction of $B$. populneus showed good scavenging ability against DPPH, none of the six fractions showed $\mathrm{IC}_{50}$ below ascorbic acid used as standard. Our results are in coherence with Kumaran [23] who reported the antioxidant ability of aqueous extract of Coleus aromaticus. The results stated in the present study showed a significant correlation with both TPC and TFC. The substantial correlation of $\mathrm{IC}_{50}$ values with TPC and TFC might be ascribed by the presence of flavonoids and other active polyphenols.

Hydroxyl radical is a potent reactive species which cause severe pathogenies to cell membrane phospholipids and react with poly unsaturated fatty acid. It is very toxic and short lived free radical which initiate chain reaction that damages the cellular integrity [24]. In the present study, the evidence of $\bullet \mathrm{OH}$ scavenging activity was estimated through the deoxyribose system. Hydrogen peroxide $\left(\mathrm{H}_{2} \mathrm{O}_{2}\right)$ reacts with ferrous, generating - $\mathrm{OH}$ that react with deoxyribose producing red color. Scavenging activity of $\cdot \mathrm{OH}$ is directly proportional to the antioxidant activity of the fraction [25]. In the current study, BPA showed the best activity with lowest $\mathrm{IC}_{50}$ value followed by $\mathrm{BPE}<\mathrm{BPB}<\mathrm{BPM}<\mathrm{BPC}<\mathrm{BPH}$, compared to the standard used. A significant correlation was observed with TPC as well as with TFC. This shows that B. populneus has active components to scavenge hydroxyl radical. Our results conformed with Majid et al. [26] who reported high activity in ethyl acetate and ethyl acetate + water extract.

The principal behind the Iron chelating assay was to decolorize the iron-ferrozine complex by the scavenger's ability or plant extract ability. The water soluble colored complex is formed by the reaction of Fe(II) with ferrozine. The complex of iron-ferrozine was obstructed by the scavenging constituents that chelates with $\mathrm{Fe}(\mathrm{II})$ thus reducing the color intensity of the solution [27]. In the present study, BPA showed the lowest $\mathrm{IC}_{50}$ value amongst the entire fractions in comparison to EDTA used as standard. Significant correlation was observed with TPC and TFC.

Griess reagent can be used to estimate the nitric oxide activity. In Griess reagent the compound sodium nitroprusside is decomposed at $\mathrm{pH} 7.2$ producing $\mathrm{NO}^{-}$in aqueous solution. In the presence of oxygen, $\mathrm{NO}^{-}$reacts and produces nitrate and nitrite. Nitrite ion production was hindered by entities having scavenging abilities by consuming the available oxygen [28]. In our current study, BPA and BPE showed relatively good results as compared to rest of the fractions and a significant correlation of $\mathrm{IC}_{50}$ values was observed both with TPC and TFC. This is owing to the fact that BPA and BPE have numerous bioactive polyphenols and other phenolic composites which have robust potential to scavenge $\mathrm{NO}^{-}$radicals that account for austere oxidative stress. The research of Duenas et al. [29] and Kilani et al. [30] is in agreement to our findings.

$\beta$-carotene bleaching assay was used to estimate the plant antioxidant potential. The principal behind this 
activity is based on linoleic acid oxidation which is caused by the formation of a complex with $\beta$-carotene. Linoleic acid hydroperoxides on reaction with $\beta$-carotene bleaches its color and the bright yellow color of the reaction mixture is reduced to light milky color. An antioxidant which is present in the reaction assortment acts on linoleic acid free radicals and releases $\beta$-carotene from the complex. This results in the restoration of the yellow color of the solution. The brighter color of the solution shows the stronger antioxidant present in the reaction while absorbance of reaction rapidly decreased in samples without antioxidants [31]. BPA fraction in our study showed the lowest $\mathrm{IC}_{50}$ value and a strong correlation with both TPC and TFC. Triantaphyllou [32] also reported promising $\beta$-carotene bleaching antioxidant activity of aqueous extracts of the herbs of the family lamiaceae.

Phosphomolybdate is another important in vitro antioxidant assay to access the total antioxidant capacity of the plant extract. The assay principal follows the conversion of Mo (VI) to Mo (V) by extract or the compound which possess antioxidant potential resulting in green phosphate Mo $(\mathrm{V})$. The electron/hydrogen donating pattern of antioxidants depends upon its structure and series of redox reactions occurring in the activity [33]. Our findings showed that aqueous fraction of $B$. populneus has good antioxidant potential due to presence of flavonoid and phenolic contents. Phosphomolybdenum assay showed significant correlation with total flavonoid contents as well as total phenolic contents. Jan et al. [34] also reported the best phosphomolybdenum activity of aqueous extract and a significant correlation with TPC and TFC.

Reducing power of B. populneus was assessed by using the potassium ferricyanide reduction method. An antioxidant compound in the test sample causes conversion of iron $\left(\mathrm{Fe}^{+3}\right)$ to ferrous $\left(\mathrm{Fe}^{+2}\right)$ by donating hydrogen and the yellow color of the reaction mixture changes to green. The intense green color in the assay shows the strong antioxidant capacity of the sample which has reducing power [35]. BPA fraction showed the highest value of reducing power when compared with ascorbic acid followed by $\mathrm{BPE}<\mathrm{BPB}<\mathrm{BPM}<\mathrm{BPC}<\mathrm{BPH}$ at $500 \mu \mathrm{g} / \mathrm{ml}$. The assay results showed significant correlation with both TPC and TFC. Our study has been supported by the report of Sahreen et al. [17] who reported best reducing power activity of methanol extract of Rumex hastatus after butanol.

Use of BPM in carbon tetrachloride intoxicated rats down regulated the expression of genes associated with endoplasmic reticulum oxidative stress and inflammatory pathways in liver [36]. The phytochemicals present in $B$. populneus might ameliorate the oxidative stress by direct scavenging of radicals and/or regulating the expression of genes. The antioxidant effects reported during this study suggest the therapeutic use of B. populneus in oxidative stress associated disorders.

\section{Experimental \\ Plant collection}

Plant collection was done from Quaid-i-Azam University, Islamabad in January-February 2017. The plant was identified by its native name and then confirmed by senior plant taxonomist; Syed Afzal Shah, Department of Plant Sciences, Quaid-i-Azam University, Islamabad. Voucher specimen (036245) was deposited at the Pakistan Herbarium, Quaid-i-Azam University, Islamabad.

\section{Preparation of extract}

The aerial parts of the plant were washed away to remove dust particles and dried under shade for few weeks. The fully dried plant material was then ground to powder and sieved through 60-mesh topology Willy Mill to get fine powder of same particle size. Extraction was carried out by mixing $1.2 \mathrm{~kg}$ of plant aerial part powder with $3 \mathrm{l}$ of commercial methanol at $25{ }^{\circ} \mathrm{C}$ for $48 \mathrm{~h}$. Filtration was performed by using Whatman No.1 filter paper. The filtrate was further processed in rotary vacuum evaporator for evaporation and obtained the methanol extract (BPM). Distilled water was used to suspend a part of BPM and then it was passed to liquid-liquid partition. The solvents were used in order of $n$-hexane (non-polar), chloroform, ethyl acetate (polar solvent), butanol (polar solvent). Fractions of these solvents were separated accordingly and named as BPH (hexane fraction), BPC (chloroform fraction), BPE (ethyl acetate fraction) and BPB (butanol fraction). The residue after last fraction was also collected and termed aqueous fraction and abbreviated as BPA. Each fraction was dried, weighed and stored for further pharmacological observations.

\section{Qualitative phytochemical analysis}

Qualitative screening of B. populneus methanol extract along with its fractions was performed to identify the active phytochemicals like flavonoids, phenols, tannins, alkaloids, saponins, terpenoids, coumarins, anthocyanins and anthraquinones.

\section{Assessment of phenols}

For qualitative assessment methodology of Harborne [37] was followed. An amount of $1 \mathrm{mg}$ of each sample was taken and $2 \mathrm{ml}$ of distilled water and $10 \%$ ferric chloride was added in it. The confirmation sign of phenols presence was formation of green or blue color. 


\section{Assessment of flavonoids}

Alkaline reagent test This test was performed by following the protocol of Trease and Evans [38]. Each sample ( $1 \mathrm{mg}$ ) was added in $1 \mathrm{ml}$ of $2 \mathrm{~N}$ sodium hydroxide. The confirmation sign of flavonoids presence was formation of yellow color.

$\mathrm{FeCl}_{3}$ test $\mathrm{Few}$ drops of $\mathrm{FeCl}_{3}$ solution were added in $1 \mathrm{ml}$ of each extract. Existence of flavonoids was indicated by formation of blackish red precipitate [39].

\section{Assessment of coumarins}

Each sample $(1 \mathrm{mg})$ was endorsed to react with $1 \mathrm{ml}$ sodium hydroxide (10\%). Formation of yellow color in test sample was an indication of the presence of coumarins [37].

\section{Assessment of saponins}

Froth formation with distilled water Each sample (2 mg) was mixed with $2 \mathrm{ml}$ of distilled water in the test tube. After this accumulation, the test sample was mixed vigorously for almost $15 \mathrm{~min}$. The formation of a soapy layer indicated the presence of saponins in test samples [37].

Emulsion test with olive oil A volume of $1 \mathrm{ml}$ of each sample was poured in test tubes followed by addition of 5-6 drops of olive oil and shaken vigorously to form a stable froth. Formation of an emulsion was the confirmatory sign of saponin presence [39].

\section{Assessment of tannins}

$\mathrm{FeCl}_{3}$ test To $1 \mathrm{mg}$ of each sample, $2 \mathrm{ml}$ of $5 \%$ ferric chloride was added. Appearance of greenish black or dark blue color was the indication of tannins presence [38].

Alkaline reagent test A volume of $2 \mathrm{ml}$ of $1 \mathrm{~N} \mathrm{NaOH}$ solution was added in $2 \mathrm{ml}$ of each plant extract. Appearance of yellow to red color showed the presence of tannins [39].

\section{Assessment of terpenoids}

Each sample $(0.5 \mathrm{mg})$ was taken in the test tube and $2 \mathrm{ml}$ of each chloroform and concentrated sulphuric acid was added to plant samples. Presence of terpenoids was indicated by the formation of brown layer in the middle of other two layers [38].

\section{Assessment of anthraquinones}

To $1 \mathrm{mg}$ of each sample, hydrochloric acid diluted to $2 \%$ was added. The appearance of red color was the confirmatory sign of anthraquinone presence [37].

\section{Assessment of anthocyanin and betacyanins}

Each sample ( $1 \mathrm{mg}$ ) was taken in the test tube and followed by the addition of $2 \mathrm{ml}$ of $1 \mathrm{~N}$ sodium hydroxide.
The test sample was boiled at $100{ }^{\circ} \mathrm{C}$ for about $10 \mathrm{~min}$. Anthocyanin presence was indicated by the formation of bluish green color while yellow color formation was indicative of betacyanin presence [38].

\section{Assessment of alkaloids}

Mayer's test Each sample $(2 \mathrm{ml})$ was allowed to react with conc. $\mathrm{HCl}$ and a special reagent named Mayer's reagent. Formation of white precipitates or appearance of green color was indication of alkaloids presence [38].

Hager's test Few drops of Hager's (Saturated picric acid solution) reagent were added to $2 \mathrm{ml}$ of each plant extract. Formation of bright yellow precipitates specified the manifestation of alkaloids [39].

\section{Assessment of glycosides}

Keller Killanis' test To $1 \mathrm{ml}$ of each plant extract, $1 \mathrm{ml}$ glacial acetic acid was added and left to cool down. After cooling two drops of $\mathrm{FeCl}_{3}$ were added and $2 \mathrm{ml}$ of concentrated $\mathrm{H}_{2} \mathrm{SO}_{4}$ along the walls of test tube was dispensed carefully. Development of reddish brown colored ring at the intersection of two layers indicated the presence of glycosides [39].

\section{Assessment of sterols}

Salkowski test To $2 \mathrm{ml}$ of each of the plant extracts, $5 \mathrm{ml}$ of chloroform was added and then $1 \mathrm{ml}$ concentrated $\mathrm{H}_{2} \mathrm{SO}_{4}$ was carefully dispensed along the walls of the tube. The appearance of reddish color in the lower layer indicated the existence of sterols [39].

\section{Assessment of vitamin C}

DNPH test Dinitrophenyl hydrazine was dissolved in concentrated sulphuric acid and allowed to react with $1 \mathrm{ml}$ of plant sample. Appearance of yellow precipitates indicated the presence of vitamin $\mathrm{C}$ in test samples.

\section{Assessment of proteins}

Xanthoproteic test According to this procedure, $1 \mathrm{ml}$ of each plant sample was treated with few drops of conc. nitric acid. Presence of proteins in test samples was indicated by the formation of yellow color.

Biuret test An amount of $0.5 \mathrm{mg}$ of each plant test solution was taken and equal volume of sodium hydroxide solution (40\%) was added to it. After that few drops of $1 \% \mathrm{CuSO}_{4}$ solution was added. Appearance of violet color in test samples manifested protein presence. 


\section{Assessment of steroids and phytosteroids}

A volume of $1 \mathrm{ml}$ of chloroform and few drops of concentrated sulphuric acid were added to $1 \mathrm{ml}$ of plant test sample. Formation of brown-colored ring indicated steroids presence whereas appearance of bluish-brown colored ring marked the presence of phytosteroids in the test samples.

\section{Assessment of phlobotannins}

To $1 \mathrm{ml}$ of each plant sample few drops of $10 \%$ ammonia solution were added. Formation of pink-colored precipitates showed the existence of phlobatannins in samples.

\section{Assessment of triterpenoids}

A volume of $1 \mathrm{ml}$ of Libermann-Buchard Reagent (conc. $\mathrm{H}_{2} \mathrm{SO}_{4}+$ acetic anhydride) was added in $1.5 \mathrm{ml}$ plant test samples. Triterpenoids were determined by the appearance of bluish-green color in the test samples.

\section{Assessment of quinones}

A volume of $1 \mathrm{ml}$ of each plant sample was allowed to react with $1 \mathrm{ml}$ concentrated sulphuric acid. Appearance of red color manifested the occurrence of quinones.

\section{Assessment of oils and resins}

Filter paper test Each plant sample was applied on filterpaper and checked for the establishment of transparent appearance which was a positive sign for the presence of oils and resins in respective test samples.

\section{Quantitative spectrophotometric phytochemical analysis}

Various fractions of B. populneus were evaluated spectrophotometrically, employing standardized procedures for the quantification of chief phytochemical constituents including phenols, flavonoids, and tannins.

\section{Total phenolic content (TPC)}

Determination of total phenolic content was done by spectrophotometer [40]. A volume of $1 \mathrm{ml}$ of each sample was mixed with $2 \mathrm{ml}$ of Phenol Folin-Ciocalteu mixture following $9 \mathrm{ml}$ of pure deionized water in a volumetric bottle having capacity up to $25 \mathrm{ml}$. After shaking, $10 \mathrm{ml}$ of $7 \% \mathrm{Na}_{2} \mathrm{CO}_{3}$ was added. Vigorous stirring was practiced following instant dilution of the final mixture with pure deionized water making final volume up to $25 \mathrm{ml}$. After keeping the final mixture at $23^{\circ} \mathrm{C}$ for at least $90 \mathrm{~min}$, the optical density was checked at wavelength of $750 \mathrm{~nm}$. The whole assay was repeated thrice for ensuring accuracy against the standard gallic acid. TPC was expressed as $\mathrm{mg}$ GAE (gallic acid equivalents)/gram dry weight extract/ fraction.

\section{Total flavonoid contents (TFC)}

The spectrophotometric technique is the easiest and affordable technique for finding out the flavonoid contents within a plant [41]. The reaction mixture was made in a test tube by the scheduled addition of $0.3 \mathrm{ml}$ plant sample, $0.15 \mathrm{ml}$ of $\mathrm{NaNO}_{2}(0.5 \mathrm{~mol} / \mathrm{l})$ along with $0.3 \mathrm{M}$ $\mathrm{AlCl}_{3} \cdot 6 \mathrm{H}_{2} \mathrm{O}$ and $3.4 \mathrm{ml}$ methanol (30\%). The assortment was kept for $5 \mathrm{~min}$ and then $1 \mathrm{ml}$ of $1 \mathrm{M} \mathrm{NaOH}$ was mixed in it. At $506 \mathrm{~nm}$ wavelength the optical density of the reaction mixture was detected using rutin as standard for comparison using concentrations $0-100 \mathrm{mg} / \mathrm{ml}$.

\section{Total tannin content (TTC)}

Procedure of Van Buren and Robinson [42], was followed for the quantification of tannin content with slight modifications. According to this procedure, $500 \mathrm{mg}$ plant sample was soaked in $50 \mathrm{ml}$ distilled water. The sample was placed on mechanical shaker for $1 \mathrm{~h}$ and then filtered. The filtrate was made up to the mark in volumetric flask $(50 \mathrm{ml})$. A volume of $2 \mathrm{ml}$ of $\mathrm{FeCl}_{3}(0.1 \mathrm{M})$ and potassium ferricyanide $(0.008 \mathrm{M})$ prepared in $\mathrm{HCl}(0.1 \mathrm{~N})$ was mixed with $5 \mathrm{ml}$ of the above filtrate. The absorbance was recorded at $200 \mathrm{~nm}$ via spectrophotometer against standard curve of gallic acid and the results were quantified as mg of gallic acid equivalents (GAE)/gram of dry plant extract [43].

\section{Quantitative non-spectrophotometric phytochemical analysis}

Brachychiton populneus fractions were quantified employing standardized non-spectrophotometric procedures for the presence of alkaloids, terpenoids, flavonoids and saponins.

\section{Quantification of alkaloids}

Alkaloids were quantified by following the procedure of [37]. A volume of $7.5 \mathrm{ml}$ of $10 \%$ acetic acid prepared in ethanol was added to $10 \mathrm{mg}$ of each plant sample. The sample assortment was covered and endorsed to stand for $4 \mathrm{~h}$ time interval. The mixture was then filtered and the subsequent filtrate was concentrated on a water-bath to reduce its volume up to one-fourth of its original volume. The extract sample was then finally precipitated by adding conc. $\mathrm{NH}_{4} \mathrm{OH}$ drop wise. The solution was endorsed to settle and the precipitates were collected after filtration. The residue obtained after washing with dilute $\mathrm{NH}_{4} \mathrm{OH}$ was completely dried and finally weighed to calculate the alkaloid percentage in respective plant samples. 


\section{Quantification of flavonoids}

Flavonoid content was quantified by following the methodology of Krishnaiah et al. [44]. Plant sample (100 mg) was extracted repeatedly with $80 \%$ aqueous methanol $(10 \mathrm{ml})$ at room temperature followed by filtration through Whatman-42 filter paper (125 mm). The filtrate was left for complete evaporation in waterbath after transferring into a crucible for complete dryness. The sample was weighed after constant weight obtained.

\section{Quantification of saponins}

Saponins were quantified following the methodology of Obadoni and Ochuko [45]. An amount of $100 \mathrm{mg}$ of each plant sample was dispersed in $15 \mathrm{ml}$ of aqueous ethanol (20\%). The suspension was heated on water bath at $55{ }^{\circ} \mathrm{C}$ for $4 \mathrm{~h}$ with constant stirring. The mixture was filtered followed by re-extraction with another $15 \mathrm{ml}$ of aqueous ethanol (20\%). Both the extracts were combined and concentrated to $4 \mathrm{ml}$ on water-bath at $90{ }^{\circ} \mathrm{C}$. Then $2 \mathrm{ml}$ of di-ethyl ether was added to the concentrate in a separating funnel. Aqueous layer was collected whereas ether layer formed was discarded. The sample was purified by repeating the above process. Finally $5 \mathrm{ml}$ of $n$-butanol was added and $n$-butanol combined extracts were washed twice with $1 \mathrm{ml}$ of $5 \%$ aqueous $\mathrm{NaCl}$. The remaining solution was completely evaporated on water-bath. A constant weight of the sample was obtained after placing it in oven and saponin content was quantified as \%age yield of plant sample.

\section{Quantification of terpenoids}

Plant sample (100 mg) was soaked in alcohol and placed for $24 \mathrm{~h}$ at room temperature. Next day the extract sample was and the filtrate was thoroughly extracted with petroleum ether. The ether extract obtained was treated as the total terpenoids in the sample [46].

\section{Antioxidant capacity determination assays}

For antioxidant potential determination seven different assays were performed to assess the antioxidant prospective against various free radicals and by different mechanisms of action. Extracts, fractions and positive standards (ascorbic acid, Rutin, catechin and gallic acid) $1 \mathrm{mg}$ were liquefied in $1 \mathrm{ml}$ analytical methanol or DMSO. These solutions were further serially diluted to $1000,500,250,125,62,31.25,15.62 \mu \mathrm{g} / \mathrm{ml}$. In all assays, same dilutions of samples and standards were used; while standards were altered according to the requirement of assay.

\section{DPPH (1, 1-diphenyl-2-picryl-hydrazyl) radical scavenging} assay

The DPPH foraging competencies of damaging effects of the free radicals were evaluated by following the methodology of Brand-Williams et al. [47] with slight modifications. The stock solution of DPPH was prepared by dissolving $0.24 \mathrm{~g}$ of it in $100 \mathrm{ml}$ of methanol and kept at $20{ }^{\circ} \mathrm{C}$ for further use. The stock solution was further diluted with methanol to optimize its absorbance $(0.908 \pm 0.02)$ at $517 \mathrm{~nm}$. Now $100 \mu \mathrm{l}$ of plant samples was mixed with $900 \mu \mathrm{l}$ of DPPH aliquot and incubated for $15 \mathrm{~min}$ at room temperature in dark. Optical density was checked at wavelength of $517 \mathrm{~nm}$ by running Ascorbic acid as standard. Antioxidant capacity was determined by following Eq. 1:

$$
\begin{aligned}
& \text { Free radical scavenging activity }(\%) \\
& \begin{aligned}
= & \left(\frac{\text { Control absorbance }- \text { Sample absorbance }}{\text { Control absorbance }}\right) \\
& \times 100
\end{aligned}
\end{aligned}
$$

\section{Hydroxyl radical scavenging assay}

Hydroxyl free radicals scavenging potential of plant extracts was assessed by using the methodology accomplished by Halliwell and Gutteridge [48]. This technique involves mixing of $500 \mu \mathrm{l}$ of $2.8 \mathrm{mM} 2$-deoxyribose, being prepared in phosphate buffer $(50 \mathrm{mM})$ maintaining its pH 7.4, EDTA $0.1 \mathrm{M}, 200 \mu \mathrm{l}$ of $100 \mathrm{mM}$ ferric chloride, $100 \mu \mathrm{l}$ of $200 \mathrm{mM} \mathrm{H}_{2} \mathrm{O}_{2}$ and $100 \mu \mathrm{l}$ of each plant sample in the reaction recipe. The reaction was initiated by the addition of $100 \mu \mathrm{l}$ of $300 \mathrm{mM}$ ascorbic acid and incubated at $37^{\circ} \mathrm{C}$ for $1 \mathrm{~h}$. After this $1 \mathrm{ml}$ of $2.8 \%$ TCA and $1 \mathrm{ml}$ of TBA (1\% weight by volume) prepared in $50 \mathrm{mM} \mathrm{NaOH}$ were added to the reaction mixture. This whole recipe was heat treated for $15 \mathrm{~min}$ in water bath and then placed for cooling. Optical density was recorded at $532 \mathrm{~nm}$. The hydroxyl radical scavenging activity was analyzed by following formula:

$$
\begin{aligned}
& \text { Free radical scavenging activity }(\%) \\
& \qquad=\left(\frac{1-\text { Sample absorbance }}{\text { Control absorbance }}\right) \times 100
\end{aligned}
$$

\section{Nitric oxide scavenging assay}

Bhaskar and Balakrishnan [49] developed the methodology using Griess reagent to assess the antioxidant potential of plant samples. Equimolar quantity of napthylenediamine $(0.1 \%)$ in distilled water and sulphanilamide (1\%) in phosphoric acid (5\%) was added to prepare griess reagent. $100 \mu \mathrm{l}$ of $10 \mathrm{mM}$ sodium nitroprusside being prepared in saline phosphate buffer was added to 
$100 \mu \mathrm{l}$ of each plant sample. Then $1 \mathrm{ml}$ of griess reagent was added to, reaction mixture, incubated for $3 \mathrm{~h}$ and analyzed spectrophotometrically at $546 \mathrm{~nm}$ by using ascorbate as a positive control. The percentage inhibition of nitric oxide radical formation was determined by following Eq. 1.

\section{Chelating power assay}

The iron (II) binding capability at multiple sites confers the antioxidant potential of plant samples following the methodology of Dastmalchi et al. [50]. A volume of $200 \mu \mathrm{l}$ of plant sample was taken as plant aliquot, $900 \mu \mathrm{l}$ of methanol and $100 \mu \mathrm{l}$ of $2 \mathrm{mM} \mathrm{FeCl} \cdot 2 \mathrm{H}_{2} \mathrm{O}$ was added to it and nurtured for $5 \mathrm{~min} .400 \mu \mathrm{l}$ of $5 \mathrm{mM}$ ferrozine was added to initiate the reaction. The whole reaction mixture was further incubated for $10 \mathrm{~min}$ and then submitted to spectrophotometry at $562 \mathrm{~nm}$ by using EDTA as standard. The chelating power was determined by Eq. 1.

\section{$\beta$-Carotene bleaching assay}

$\beta$-Carotene bleaching activity of the plant was assessed by following the methodology suggested by Elzaawely et al. [51]. The format of this protocol was that a mixture of $\beta$-carotene was made by adding $2 \mathrm{mg}$ of it with that of $10 \mathrm{ml}$ chloroform followed by mixing $200 \mathrm{mg}$ of Tween 80 and $20 \mathrm{mg}$ of linoleic acid. The chloroform was evaporated out of the mixture by the help of vacuum and then $50 \mathrm{ml}$ of distilled water was added to it, vigorously vortexed to get a uniform emulsion of $\beta$-carotene linoleate. Then $250 \mu \mathrm{l}$ of freshly prepared emulsion was added to $30 \mu \mathrm{l}$ of each plant sample and optical density was measured at time $0 \mathrm{~h}$ at wavelength $470 \mathrm{~nm}$. The reaction mixture was kept at $45^{\circ} \mathrm{C}$ for $2 \mathrm{~h}$ and the final optical density was measured again. Catechin served as standard in this assay. Inhibition of $\beta$-carotene was detected by slight alteration in the formula used by Mallet et al. [52]

$$
\begin{aligned}
\% \text { inhibition }= & {\left[\left(\mathrm{A}_{\mathrm{A}(120)}-\mathrm{A}_{\mathrm{C}(120)}\right) /\right.} \\
& \left.\left(\mathrm{A}_{\mathrm{C}(0)}-\mathrm{A}_{\mathrm{A}(120)}\right)\right] \times 100
\end{aligned}
$$

where $\mathrm{A}_{\mathrm{A}}$ (120) is the antioxidant absorbance at $\mathrm{t}=120 \mathrm{~min}, \mathrm{~A}_{\mathrm{C}}(120)$ is the control absorbance at $\mathrm{t}=120 \mathrm{~min}$, and $\mathrm{A}_{\mathrm{C}(0)}$ is the control absorbance at $\mathrm{t}=0 \mathrm{~min}$.

\section{Reducing power assay}

By the method of Landry et al. [53] reducing power activity was calculated. Plant extract $2 \mathrm{ml}$ was mixed with $2 \mathrm{ml}$ of $0.2 \mathrm{M}$ phosphate buffer ( $\mathrm{pH} 6.6$ ) and $2 \mathrm{ml}$ of potassium ferricyanide $(10 \mathrm{mg} / \mathrm{l})$ were mixed up and incubated at $50{ }^{\circ} \mathrm{C}$ for $20 \mathrm{~min}$. Then $2 \mathrm{ml}$ of trichloroacetic acid (TCA)
$(100 \mathrm{mg} / \mathrm{l})$ was added to the solution. After this $2 \mathrm{ml}$ of the above solution was picked up and diluted with $2 \mathrm{ml}$ of pure $\mathrm{H}_{2} \mathrm{O}$ and $0.4 \mathrm{ml}$ of $\mathrm{FeCl}_{3}(0.1 \%)$ in a test tube. Standard used in this assay was gallic acid. Optical density was measured after $10 \mathrm{~min}$ at $700 \mathrm{~nm}$.

\section{Phosphomolybdenum assay}

The antioxidant capabilities of the plant sample was assured by phosphomolybdenum assay as per described in the methodology of Umamaheswari and Chatterjee [54]. Phosphomolybdenum reagent solution was prepared by mixing $\mathrm{Na}_{3} \mathrm{PO}_{4}(28 \mathrm{mM})$ and $\mathrm{H}_{2} \mathrm{SO}_{4}(0.6 \mathrm{M})$ with that of ammonium molybdate $(4 \mathrm{mM})$. The reaction mixture is heated at $95^{\circ} \mathrm{C}$ in water bath for 90 min taking a good care that it is fully covered with silver foil to avoid direct light exposure. After this heat treatment, the reaction mixture was cooled at room temperature for some time and submitted to spectrophotometric analysis at $765 \mathrm{~nm}$. Ascorbic acid serves as a standard in this assay.

\section{Statistical analysis}

Experimental data results were conveyed in the form of mean \pm standard deviation (SD) having triplicate analysis. The data was recognized and investigated by using the computerized GraphPad Prism (5.0) software to calculate the $\mathrm{IC}_{50}$ values. Statistix software 8.1 was used for further statistical analysis followed by applying ANOVA (One-way analysis variance) for the calculation of differences among various groups. The data is given as Additional file 1 .

\section{Conclusion}

The present study indicated the presence of higher polyphenol content and rich phytochemical assortment of $B$. populneus might be the key players in scavenging of oxidative stress inducing species. The result also suggests that the presence of various chemicals in this plant did not assort according to the polarity of solvents used in this study. This might led to the non-directional distribution and accumulation of chemicals in terms of yield.

\section{Additional file}

Additional file 1. Phytochemical and antioxidant assays data. The data include the DPPH, Iron chelation, nitric oxide, hydroxyl, B-carotene, phenolics and flavonoids, phosphomolybdenum and reducing power assays sub files. It include all the data generated and analyzed for this study.

\section{Abbreviations}

BPM: B. populneus methanol extract; BPH: B. populneus n-hexane fraction; BPC: B. populneus chloroform fraction; BPE: B. populneus ethyl acetate fraction; BPB: B. populneus butanol fraction; BPA: B. populneus aqueous fraction; TFC: total flavonoid content; TPC: total phenolic content. 


\section{Authors' contributions}

RB made significant contribution in the collection of data, analysis and drafting of the manuscript. MRK provided the necessary research facilities and made significant contribution in conception and designing, and revised the manuscript for intellectual content. MS, SA and ZZ participated in the collection of data and analysis. All authors read and approved the final manuscript.

\section{Acknowledgements}

The facilities for the study were provided by Dr. Muhammad Rashid Khan, Professor, Department of Biochemistry, Faculty of Biological Sciences, Quaid-iAzam University Islamabad, Islamabad Pakistan.

\section{Competing interests}

The authors declare that they have no competing interests.

\section{Availability of data and materials}

All data generated or analysed during this study are included in this published article [and its Additional file 1].

\section{Funding}

The project was funded by Department of Biochemistry, Faculty of Biological Sciences, Quaid-i-Azam University Islamabad, Islamabad Pakistan.

\section{Publisher's Note}

Springer Nature remains neutral with regard to jurisdictional claims in published maps and institutional affiliations.

Received: 28 December 2017 Accepted: 2 March 2019

Published online: 21 March 2019

\section{References}

1. Kasote DM, Katyare SS, Hegde MV, Bae H (2015) Significance of antioxidant potential of plants and its relevance to therapeutic applications. Int J Biol Sci 11:982

2. Santos HFd, Campos JF, Santos CMd, Balestieri JBP, Silva DB, Carollo CA, Picoli Souza K, Estevinho LM, dos Santos EL (2017) Chemical profile and antioxidant, anti-inflammatory, antimutagenic and antimicrobial activities of geopropolis from the stingless bee Melipona orbignyi. Int J Mol Sci 18:953

3. El Toumy S, El Sharabasy F, Ghanem H, El Kady M, Kassem A (2011) Chemical constituents and pharmacological activities of Zilla spinosa. Planta Med 77:51

4. Song J, Yeo SG, Hong EH, Lee BR, Kim JW, Kim J, Jeong H, Kwon Y, Kim $H$, Lee S (2014) Antiviral activity of hederasaponin B from Hedera helix against enterovirus 71 subgenotypes C3 and C4a. Biomol Ther 22:41

5. Savithramma N, Rao ML, Suhrulatha D (2011) Screening of medicinal plants for secondary metabolites. Middle East J Sci Res 8:579-584

6. Devkar RA, Chaudhary S, Adepu S, Xavier SK, Chandrashekar KS, Setty MM (2016) Evaluation of antiurolithiatic and antioxidant potential of Lepidagathis prostrata: a Pashanbhed plant. Pharm Biol 54:1237-1245

7. Birben E, Sahiner UM, Sackesen C, Erzurum S, Kalayci O (2012) Oxidative stress and antioxidant defense. World Allergy Organ J 5:9

8. Kazeem Ml, Ashafa AOT (2016) Antioxidant and inhibitory properties of Dombeya burgessiae leaf extracts on enzymes linked to diabetes mellitus. Trans R Soc S Afr 71:167-174

9. Boland DJ, Brooker MIH, Chippendale G, Hall N, Hyland B, Johnston R, Kleinig D, McDonald M, Turner J (2006) Forest trees of Australia. CSIRO publishing, Clayton

10. Cunningham G, Mulham W, Milthorpe P, Leigh J (1992) Plants of western new South Wales. Inkata Press, Sydney

11. Zeid AHA, Farag MA, Hamed MAA, Kandil ZAA, El-Akad RH, El-Rafie HM (2017) Flavonoid chemical composition and antidiabetic potential of Brachychiton acerifolius leaves extract. Asian Pac J Trop Biomed 7:389-396

12. Arif N, Yadav V, Singh S, Kushwaha BK, Singh S, Tripathi DK, Vishwakarma K, Sharma S, Dubey N, Chauhan D (2016) Assessment of antioxidant potential of plants in response to heavy metals. In: Singh A, Prasad S, Singh R (eds) Plant responses to xenobiotics. Springer, Berlin, pp 97-125
13. Shah NA, Khan MR, Naz K, Khan MA (2014) Antioxidant potential, DNA protection, and HPLC-DAD analysis of neglected medicinal Jurinea dolomiaea roots. BioMed Res Int. https://doi.org/10.1155/2014/726241

14. Sahreen S, Khan MR, Khan RA (2014) Comprehensive assessment of phenolics and antiradical potential of Rumex hastatus D. Don. roots. BMC Complement Altern Med 14:47

15. Dhawan D, Gupta J (2017) Comparison of different solvents for phytochemical extraction potential from Datura metal plant leaves. Int J Biol Chem 11:17-22

16. Cai Y, Zhang J, Chen NG, Shi Z, Qiu J, He C, Chen M (2016) Recent advances in anticancer activities and drug delivery systems of tannins. Med Res Rev 37:665-701

17. Dzoyem JP, Eloff JN (2015) Anti-inflammatory, anticholinesterase and antioxidant activity of leaf extracts of twelve plants used traditionally to alleviate pain and inflammation in South Africa. J Ethnopharmacol 160:194-201

18. Ng YP, Or TCT, Ip NY (2015) Plant alkaloids as drug leads for Alzheimer's disease. Neurochem Int 89:260-270

19. Hashmi M, Khan A, Farooq U, Khan S (2018) Alkaloids as cyclooxygenase inhibitors in anticancer drug discovery. Curr Protein Pept Sci 19:292-301

20. Chaieb I (2010) Saponins as insecticides: a review. Tunis J Plant Prot 5:39-50

21. Chanda S, Dave R (2009) In vitro models for antioxidant activity evaluation and some medicinal plants possessing antioxidant properties: an overview. Afr J Microbiol Res 3:981-996

22. Alam MN, Bristi NJ, Rafiquzzaman M (2013) Review on in vivo and in vitro methods evaluation of antioxidant activity. Saudi Pharm J 21:143-152

23. Kumaran A (2006) Antioxidant and free radical scavenging activity of an aqueous extract of Coleus aromaticus. Food Chem 97:109-114

24. Souza BS, Dantas RF, Cruz A, Sans C, Esplugas S, Dezotti M (2014) Photochemical oxidation of municipal secondary effluents at low $\mathrm{H}_{2} \mathrm{O}_{2}$ dosage: study of hydroxyl radical scavenging and process performance. Chem Eng J 237:268-276

25. Herraiz T, Galisteo J (2015) Hydroxyl radical reactions and the radical scavenging activity of $\beta$-carboline alkaloids. Food Chem 172:640-649

26. Majid M, Khan MR, Shah NA, Haq IU, Farooq MA, Ullah S, Sharif A, Zahra Z, Younis T, Sajid M (2015) Studies on phytochemical, antioxidant, antiinflammatory and analgesic activities of Euphorbia dracunculoides. BMC Complement Altern Med 15:349

27. Wu L, Du Y, Lok J, Lo EH, Xing C (2015) Lipocalin-2 enhances angiogenesis in rat brain endothelial cells via reactive oxygen species and irondependent mechanisms. J Neurochem 132:622-628

28. Kanugula AK, Gollavilli PN, Vasamsetti SB, Karnewar S, Gopoju R, Ummanni R, Kotamraju S (2014) Statin-induced inhibition of breast cancer proliferation and invasion involves attenuation of iron transport: intermediacy of nitric oxide and antioxidant defence mechanisms. FEBS J 281:3719-3738

29. Duenas M, Hernandez T, Estrella I (2006) Assessment of in vitro antioxidant capacity of the seed coat and the cotyledon of legumes in relation to their phenolic contents. Food Chem 98:95-103

30. Kilani S, Sghaier MB, Limem I, Bouhlel I, Boubaker J, Bhouri W, Skandrani I, Neffatti A, Ammar RB, Dijoux-Franca MG (2008) In vitro evaluation of antibacterial, antioxidant, cytotoxic and apoptotic activities of the tubers infusion and extracts of Cyperus rotundus. Bioresour Technol 99:9004-9008

31. Tan Z, Shahidi F (2013) Antioxidant activity of phytosteryl phenolates in different model systems. Food Chem 138:1220-1224

32. Triantaphyllou GB, Dimitrios Boskou K (2001) Antioxidative properties of water extracts obtained from herbs of the species Lamiaceae. Int J Food Sci Nutr 52:313-317

33. Gupta K, Maurya S, Agarwal S, Kushwaha A, Kumar R (2016) Antioxidant assessment of extracts obtained through hot extraction process. Cell Mol Biol 62:129

34. Jan S, Khan MR, Rashid U, Bokhari J (2013) Assessment of antioxidant potential, total phenolics and flavonoids of different solvent fractions of Monotheca buxifolia fruit. Osong Public Health Res Perspect 4:246-254

35. Wang J, Hu S, Nie S, Yu Q, Xie M (2016) Reviews on mechanisms of in vitro antioxidant activity of polysaccharides. Oxid Med Cell Longev. https://doi. org/10.1155/2016/5692852

36. Batool R, Khan MR, Zai JA, Ali S, Maryam S, Naz I, Bibi S (2018) Brachychiton populneus (Schott \& Endl.) R.Br. ameliorate carbon tetrachloride 
induced oxidative stress through regulation of endoplasmic reticulum stress markers and inflammatory mediators in Sprague-Dawley male rats. Biomed Pharmacother 107:1601-1610

37. Harborne JB (1998) Phytochemical methods a guide to modern techniques of plant analysis. SSBM, Berlin

38. Trease G, Evans WC (1989) Trease and Evans' pharmacognosy: a physician's Guide to Herbal Medicine, 13th edn. Bailliere Tindall, London, p 912

39. Archana P, Samatha T, Mahitha B, Chamundeswari NR (2012) Preliminary phytochemical screening from leaf and seed extracts of Senna alata $\mathrm{L}$. Roxb-an Ethno medicinal plant. Int J Pharm Biol Res 3:82-89

40. Kim DO, Jeong SW, Lee CY (2003) Antioxidant capacity of phenolic phytochemicals from various cultivars of plums. Food Chem 81:321-326

41. Park YS, Jung ST, Kang SG, Heo BG, Arancibia-Avila P, Toledo F, Drzewiecki J, Namiesnik J, Gorinstein S (2008) Antioxidants and proteins in ethylenetreated kiwifruits. Food Chem 107:640-648

42. Van Buren JP, Robinson WB (1969) Formation of complexes between protein and tannic acid. J Agric Food Chem 17:772-777

43. Singh R, Verma PK, Singh G (2012) Total phenolic, flavonoids and tannin contents in different extracts of Artemisia absinthium. J Intercult Ethnopharmacol 1:101-104

44. Krishnaiah D, Devi T, Bono A, Sarbatly R (2009) Studies on phytochemical constituents of six Malaysian medicinal plants. J Med Plants Res 3:067-072

45. Obadoni B, Ochuko P (2002) Phytochemical studies and comparative efficacy of the crude extracts of some haemostatic plants in Edo and Delta States of Nigeria. GJPAS 8:203-208
46. Ferguson NM (1956) A Text book of pharmacognosy. New Delhi, MacMilan Company, p 191

47. Brand-Williams W, Cuvelier M, Berset C (1995) Use of a free radical method to evaluate antioxidant activity. Food Sci Technol 28:25-30

48. Halliwell B, Gutteridge JM (1981) Formation of a thiobarbituric-acid-reactive substance from deoxyribose in the presence of iron salts: the role of superoxide and hydroxyl radicals. FEBS Lett 128:347-352

49. Bhaskar H, Balakrishnan N (2009) In vitro antioxidant property of laticiferous plant species from western ghats Tamilnadu, India. Int J Health Res. https://doi.org/10.4314/ijhr.v2i2.55413

50. Dastmalchi K, Dorman HD, Oinonen PP, Darwis Y, Laakso I, Hiltunen R (2008) Chemical composition and in vitro antioxidative activity of a lemon balm (Melissa officinalis L.) extract. Food Sci Technol 41:391-400

51. Elzaawely AA, Xuan TD, Koyama H, Tawata S (2007) Antioxidant activity and contents of essential oil and phenolic compounds in flowers and seeds of Alpinia zerumbet (Pers.) BL Burtt. \& RM Sm. Food Chem 104:1648-1653

52. Mallet J, Cerrati C, Ucciani E, Gamisans J, Gruber M (1994) Antioxidant activity of plant leaves in relation to their alpha-tocopherol content. Food Chem 49:61-65

53. Landry J, Sutton A, Tafrov ST, Heller RC, Stebbins J, Pillus L, Sternglanz R (2000) The silencing protein SIR2 and its homologs are NAD-dependent protein deacetylases. Proc Natl Acad Sci 97:5807-5811

54. Umamaheswari $\mathrm{M}$, Chatterjee $T$ (2008) In vitro antioxidant activities of the fractions of Coccinia grandis L. leaf extract. Afr J Tradit Complement Altern Med 5:61-73
Ready to submit your research? Choose BMC and benefit from:

- fast, convenient online submission

- thorough peer review by experienced researchers in your field

- rapid publication on acceptance

- support for research data, including large and complex data types

- gold Open Access which fosters wider collaboration and increased citations

- maximum visibility for your research: over 100M website views per year

At BMC, research is always in progress.

Learn more biomedcentral.com/submissions 